\title{
Language and HIV communication
}

This article was published in the following Dove Press journal:

HIVIAIDS - Research and Palliative Care

20 September 2017

Number of times this article has been viewed

\section{Vickie A Lynn}

Department of Community and Family Health, College of Public Health, University of South Florida, Tampa, FL, USA
Correspondence: Vickie A Lynn Department of Community and Family Health, College of Public Health, University of South Florida, I320I Bruce B. Downs Boulevard, MDC56, Tampa, FL 33612-3805, USA

Tel +I 8I34I7 I522

Email vlynn@health.usf.edu

\section{Dear editor}

I am writing to comment on Kontomanolis et al's recent article entitled "The social stigma of HIV-AIDS: society's role". ${ }^{1}$ Although I applaud the authors for writing about this important topic and I wholeheartedly agree that HIV-related stigma is devastating to women living with HIV, I want to point out that using stigmatizing language when writing an article about HIV-related stigma is counterproductive.

The first sentence of the Abstract is medically incorrect and fuels the myths associated with HIV and AIDS. AIDS is not a "devastating and deadly disease". It is a diagnosis, a syndrome, a collection of diseases. One must be careful when referring in speech or writing to HIV and AIDS to ensure that terminology is medically correct, debarring social stigma. Research articles need to reflect the differences between HIV and AIDS rather than confuse the terms.

There are also added stigmatizing phrases and terminology in the article. For example, the authors pointed out that "Stigma is a multifaceted social structure that has its own pathway; it starts with labeling, separation, status loss, and ends up in discrimination" (p. 112), yet labels are used throughout the article. Tagging women as "AIDS patients" or "HIV positive women" further stigmatizes, dehumanizes, and reduces them to a diagnosis, which adds to the stigmatization of this population.

To reduce stigma and discrimination, it is vital that researchers use medically appropriate and preferred language, that is, the language preferred by the population of people that the researchers are describing. The use of "people-first language", as suggested by the Denver Principles and Dilmitis et al, puts the person before the diagnosis. ${ }^{2,3}$ Using "women living with HIV" or "women diagnosed with HIV" is preferred and less stigmatizing. People-first language emphasizes the person not their illness, diagnosis, or label.

Over 35 years into the HIV epidemic, researchers and health professionals are still using stigmatizing language regarding this population. As a scientist and as a woman living with HIV for 32 years, I urge the scientific community to rethink the use of language and how it affects HIV-related stigma.

\section{Disclosure}

The author reports no conflicts of interest in this communication. 


\section{References}

1. Kontomanolis EN, Michalopoulos S, Gkasdaris G, Fasoulakis Z. The social stigma of HIV-AIDS: society's role. HIV AIDS (Auckl). 2017;9:111-118.

2. Denver Principles. Statement from the Advisory Committee of People with HIV/AIDS. 1983. Available from: http://www.nlm.nih.gov/survivingandthriving/education/documents/OB2216-DenverPrinciples.pdf. Accessed August 28, 2017.

3. Dilmitis S, Edwards O, Hull B, et al. Language, identity and HIV: why do we keep talking about the responsible and responsive use of language? Language matters. J Int AIDS Soc. 2012;15(Suppl 2):17990. 


\section{Author's reply \\ Emmanuel $\mathrm{N}$ Kontomanolis}

Department of Obstetrics and Gynecology, Democritus University of Thrace, Alexandroupolis, Greece

Correspondence: Emmanuel N Kontomanolis

Department of Obstetrics and Gynecology, Democritus University of Thrace, District of Dragana, Prefecture of Evros, Alexandroupolis 68100, Greece

Tel +306977367245

Email mek-2@otenet.gr

\section{Dear editor}

In our civilized world, all human beings are entitled to their own opinion. I agree that AIDS is a collection of diseases, a syndrome. A good number of people though have passed away because of AIDS. I do admire the courage of our colleague and congratulate her on declaring in written form that she is an AIDS patient since very few people have the strength to do that in our established society today.

The purpose of our article was to point out the existence of stigma and labeling on these patients, to sensitize society that social isolation is improper and demoralizing. Our intention to express our opinion has been misunderstood.

As a trainee years ago in a European country, during our daily visit in the ward, we walked by a room with its drapes closed. We were not allowed to enter the room and were told by the leading clinician that within the room there was an AIDS patient. This is what I call stigma.
I strongly believe that a good number of people worldwide would hesitate to disclosure their aforementioned health problem, despite the good efforts throughout the years to eliminate their fear of being left aside.

Scientific language must be strict, straightforward, evidence-based and devoid of emotions. This is actually the real meaning of science, the opportunity to speak, write, and express different viewpoints. It is not always necessary for scientific opinions to coincide.

Even nowadays, I believe that regardless of how many articles will be written, traces of stigma will always be there present in societies. It is the severity and seriousness of the disease that makes things different. Unfortunately, it is the origin of the human nature that cancels any effort made towards the annihilation of labeling; it is the weakness of human nature that feeds ethical derailing. ${ }^{1,2}$ To conclude, there was no intention of either insulting or excluding social groups.

\section{Disclosure}

The author reports no conflicts of interest in this communication.

\section{References}

1. Kontomanolis EN, Michalopoulos S, Gkasdaris G, Fasoulakis Z. The social stigma of HIV-AIDS: society's role. HIV AIDS (Auckl). 2017;9:111-118.

2. Lesky A. History of Ancient Greek Literature. 5th ed. Thessaloniki: Kiriakides Brothers; 1990.

Dove Medical Press encourages responsible, free and frank academic debate. The content of the HIV/AIDS - Research and Palliative Care 'letters to the editor' section does not necessarily represent the views of Dove Medical Press, its officers, agents, employees, related entities or the HIV/AIDS - Research and Palliative Care editors. While all reasonable steps have been taken to confirm the content of each letter, Dove Medical Press accepts no liability in respect of the content of any letter, nor is it responsible for the content and accuracy of any letter to the editor.

\section{Publish your work in this journal}

HIV/AIDS - Research and Palliative Care is an international, peerreviewed open access journal focusing on advances in research in HIV its clinical progression and management options including antiviral treatment, palliative care and public healthcare policies to control viral spread. The journal is included in PubMed. The manuscript man- agement system is completely online and includes a very quick and fair peer-review system, which is all easy to use. Visit http://www.dovepress. com/testimonials.php to read real quotes from published authors. 